\title{
The Role of Working Capital Accruals on Earnings Quality and Stock Return
}

\author{
Javad Izadi Zadeh Darjezi ${ }^{1}$, Ehsan Khansalar $^{2}$ \& Andrew Holt ${ }^{3}$ \\ ${ }^{1}$ Management School, Lancaster University, Lancaster, United Kingdom \\ ${ }^{2}$ Kingston Business School, Kingston University, London, United Kingdom \\ ${ }^{3}$ Department of Accounting, Metropolitan State University of Denver, United States \\ Correspondence: Javad Izadi Zadeh Darjezi, Management School, Lancaster University, Lancaster, LA1 4YW, \\ United Kingdom. E-mail: izady1347@yahoo.com
}

Received: June 1, 2015

Accepted: June 18, 2015

Online Published: August 25, 2015

doi:10.5539/ijef.v7n9p1

URL: http://dx.doi.org/10.5539/ijef.v7n9p1

\begin{abstract}
A failure to beat earnings expectations often results in an immediate fall in a firm's stock price, while exceeding market expectations is normally rewarded by investors in the form of an increased stock price. As a result, managers may have a vested interest in 'managing' the reported earnings growth when remuneration packages are linked to corporate profitability. Investors may be misled by this earnings management process if they are fail to consider the quality of earnings when assessing stock returns. Investors can determine earnings quality through the information disclosures provided by management, although such information may not be routinely provided by corporate management teams. In situations where the market focuses primarily on firms' reported income and fails to consider the quality of accounting earnings, there may be temporary divergence of stock prices from their correct values. Where the market focuses on the reported income figure in a firm's income statement it fails to consider information about earnings quality, such as the disclosures about working capital accruals. The Financial Accounting Standards Board (FASB) states that the usefulness of accounting information is the principal objective of financial statements (FASB, 1978). This paper investigates whether the usefulness of accounting information in the decision making process is enhanced by recognizing the impact that information about earnings quality may have on stock returns. More specifically, the paper focuses on the impact of accounting accruals as the main measurement and indicator of earnings quality.
\end{abstract}

Keywords: earnings quality, working capital accruals, stock return

\section{Introduction}

Within the accounting literature, the usefulness of the earnings figure is often debated from the perspective of value-relevance and its strong association with stock market values (Holthausen \& Watts, 2001). Earlier studies (Ball \& Brown, 1968; Lev, 1989; Lev \& Zarowin, 1999; Vafeas, 2000; Barth et al., 2001) suggest that while the information content of earnings is fully reflected in the market price of equity its disclosure was still helpful to investors. More recently, there has been increased concern about the quality of reported earnings and whether these accounting figures reflect the operating fundamentals of firms. The traditional view is that stock markets primarily focus on the 'bottom-line' reported income within income statement and largely ignore the quality of those accounting earnings. As a result, the determination of accounting earnings quality may have predictive power for explaining fluctuations in stock prices.

The level of each period's reported earnings is clearly influenced by the use of accruals accounting, as its allocates cash flows to certain time periods to make financial reports more useful for measuring the periodic performance of a firm (Dechow et al., 1998; Liu et al., 2002). However, one consequence of the use of accruals accounting is that it may also be used for earnings management, a process whereby management engage in a conscious intervention and manipulation of the financial reporting process for their own private gain (Schipper, 1989).

Managerial judgement is a fundamental part of the financial reporting process under both U.S. generally accepted accounting principles (GAAP) and International Financial Reporting Standards (IFRS). Judgment is necessary for choosing among suitable and acceptable accounting techniques for each business transaction, such 
as selecting a specific depreciation or inventory valuation method. Managers must also exercise judgment on inventory levels and receivable policies as a part of their management of working capital, which directly affects cost distributions and net revenues. Managers also determine the current authorization or deferral of expenditure, such as for research and development (R\&D) expenditures.

Although, earlier research shows that the high level of financial accounting accruals utilized by certain firms in the United States (U.S.) may face enforcement action from the Securities and Exchange Commission (SEC), there is no evidence to suggest that managers at firms with high levels of accruals intentionally manipulate earnings through the use of accruals accounting (see Dechow et al., 1996). However, Chan et al. (2006) identify a number of other reasons why accruals are associated with future returns. They argue that the impact of accruals may emerge from the same examples of investor actions as other extensively documented regularities in stock returns, for instance the book-to-market effect as well as price and earnings momentum.

Managers can communicate their personal information about the performance of companies through financial reporting (Demski, 1998; Arya et al., 2003; Guay, 2006). Also, managers can use their discretion to structure transactions to alter financial reports and mislead certain users about the economic performance of the firm (Healy \& Whalen, 1999). Despite these issues, an accruals-based earnings figure does present more useful information about a company's performance than a cash-flow-based earnings figure. While accrual accounting research has been a very active field of research, providing insights in the financial reporting procedures in general and accrual accounting in particular, there is no evidence of managers deliberately manipulating accruals-based accounting earnings at firms with high levels of accruals. As a result, rather than a 'manipulation effect', the impact of accruals may similar to other examples of investor actions in influencing stock returns e.g. the book-to-market ratio effect (Note 1).

This paper investigates whether accruals, as a measure of earnings quality, are associated with future stock returns. Chen et al. (2006) argue that accruals accounting identifies the differences between a company's accounting earnings and its related cash flows. Large positive accruals occur when periodic accounting earnings are higher than periodic cash flows. The differences between earnings and cash flow arise as accounting principles related to the timing and matching of revenues and expenses differ from the measurement of cash receipts and payments. For example, credit sales can be included in periodic earnings and depreciation on assets is deducted from annual revenue although there is no cash expenditure involved. High levels of accruals may reflect increases in any non-cash-based current assets or decreases in current liability accounts. Where investors focus primarily on the bottom-line of reported income they may be misled by increases in poor quality periodic earnings.

\section{Related Research}

Although the concept of earnings quality has been widely debated in the accounting literature, there is little agreement about what it encompasses and how it should be measured. Various factors, including the degree to which the economic actuality of the firm is replicated, have been identified as features that increase the quality of profits. Other items, including approximate levels of discretionary accruals, are identified as characteristics of poorer quality earnings (see Siegel, 1991). Kothari (2001) identifies that management discretion and investor's corporate evaluation as relevant factors that affect earnings quality. Francis et al. (2004) document seven characteristics of earnings quality, including quality of accruals, predictability, persistence, value relevance, smoothness, conservatism and timeliness.

Accounting earnings quality is investigated from the viewpoint of value relevance or its effectiveness for making investments. For instance, Scott (2003) proposes that as earnings quality and earnings response coefficients (ERC) have a positive correlation, earnings quality can be defined by the extrapolative capability of the return. Dechow et al. (1995) suggest that accounting basics drive nondiscretionary accruals and assume that the residuals errors which comes from a regression model of total accruals against accounting basics explain earnings management. The prediction errors as residual values are also used as a contrary measure of earnings quality (see Schipper \& Vincent, 2003). Earlier evidence in the accounting literature shows that mispricing does exist in the market due to the accruals anomaly, where abnormal returns can be produced from a trading strategy based on total accruals (Sloan, 1996) and unexpected accruals (Xie, 2001). More recent studies have investigated the opportunity to earn abnormal returns from accrual quality. Ecker et al. (2006) found some evidence of abnormal returns from a trading strategy based on the systematic component of accrual quality according to Fama-French risk factor model.

In terms of predictive ability, the complexity of future forecasting by analysts should also be included in the measurement of earnings quality. The impact of hesitation in analysts' earnings predictions based upon the 
association between unexpected earnings and unexpected returns was investigated by Imhoff and Gerald (1992). Their finding shows that there is a systematic relationship between ex-ante uncertainty (for which the variance in analysts' earnings forecasts prior to the firm's annual earnings announcement which is used as an alternative) and the information content of earnings. Crabtree and Maher (2005) investigate the association between predictability of earnings; which is calculated by the difference between the analysts' prediction and actual earnings, and the cost of debt calculated according to its influence on the bond rating. Their results demonstrate that the level of predictability of accounting earnings is positively related with a firm's bond rating, and has a negative association with the yield offered. Though, managerial actions to meet analysts' forecasts may reduce the earnings quality (see Schipper \& Vincent, 2003).

While accounting accruals may contain useful information about operating activities, markets generally react gradually to this information. The accrual components, for example changes in inventories, accounts receivables and payables are usually employed by market analysts as indicators of business conditions. A company that is experiencing difficulties in creating revenue or is over producing will experience a build-up of inventories. Likewise, poor credit control may lead to increase in accounts payables. While companies with high levels of accruals are not essentially falling into financial distress, the accrual components may indicate that revenues growth is slowing, although bottom-line earnings may stay unchanged in the short-term. Empirical evidence suggests that markets typically under react to the information contained in a variety of accounting-based disclosures (e.g. Chan et al., 1996; Abarbanell \& Piotroski, 2000). Therefore, the suggestion is that markets will also be slow to react to the information contained within accounting accruals. Specially, accruals are provided as a result of a relative delay in economic conditions, although initially the market does not fully react to this signal. Consequently, accruals lead to a subsequent negative stock price reaction.

A number of studies have used the ratio of net income to stock price to show the cross section of upcoming returns (e.g. Basu, 1977; Fama \& French 1992). Financial analysts believe that measuring firm's performance using net income is a noisy measurement as managers have discretion as to the measurement and recognition of expenses and revenues. Schipper and Vincent (2003) show that total accruals as an earnings quality construct which is separated from unexpected accruals, even though total accruals consists of expected and unexpected accruals. Bayley and Taylor (2007) demonstrate that unexpected accrual measures do not present simple measures of total accruals to recognise earnings overstatements. Some studies use cash flow relative to stock price as a proxy measurement for profitability. Cash flow measurements are typically less volatile as they are less open to manipulation by managers when compared to earnings. Furthermore, as there is no agreement in the investment industry as to the best measurement of cash flow, managerial manipulation of cash flow would have less overall impact. As a result of these observations, cash flow in general has stronger descriptive power for predicting future returns. Sloan (1996) shows an interesting return anomaly related to accruals. He found that stocks with large positive levels of accruals in a specified year experience lower level of returns in following years. Collins and Hribar (2000) extended Sloan's findings by using quarterly accruals. They found that large positive accruals are an indication of earnings management, however investors did not recognise this event and are misled into believing that next year's profitability will remain high. Other researchers have attempted to investigated whether the mispricing can be attributed to the portion of accruals that reflect opportunistic managerial discretion (Note 2).

This research builds on the existing literature by examining how managers use judgment in financial reporting through accounting accruals to disclose earnings which best reflect corporate performance. Certain researchers e.g. Dechow (1994) and Liu et al. (2002) argue that changing the accruals recognition of cash flows may make financial reports more useful for revealing the underlying performance of the firm. Similarly, Schipper (1989) questions whether the effect of accruals is to actually increase earnings quality and render financial reports more useful for users. Given that both U.S. GAAP and IFRS require management to make accounting judgments and estimates, if accruals are employed for earnings management, the essential issue is how managers employ accruals to create earnings that are of high quality. In the remainder of this paper, empirical evidence is presented using stock price data from the United Kingdom (U.K), which represents the second-largest equity market in the world size and whose listing requirements require the use of accounting standards that are comparable to U.S. GAAP in their quality. Using this U.K. data, predictive regressions are performed on various accruals components to assess their differential impact on returns.

\section{Sample Selected and Methodology}

The data set employed for sample selection was obtained from the Worldscope and Thomson One Banker databases of stock price and accounting data for all U.K. listed firms. Financial firms with Standard Industrial Classification (SIC codes 9000) were removed from the sample. In order to measure accruals effectively, all non- 
standard reporting periods were excluded. Once these adjustments were performed, the remaining firm years with a complete set of observations totaled 5,026. After lag operations, the total number of firm years within the sample equaled 3850 observations.

Teoh et al. (1998) classify accruals based on growth in sales and equipment into two groups; discretionary and non-discretionary accruals. According to their research accruals generally arise come from sales growth, thus sales is defined as a component of accounting earnings. They also document that the abnormal portion of accruals comes from the difference between changes in non-cash current assets and the change in operating current liabilities. (Note 3) Their results signify that discretionary working capital accruals have a higher impact on expected returns. Consequently, consistent with earnings management, they discover the suggestion that high level of discretionary current accruals can determine post-issue long-run earnings and return deficits.

Earlier research focused on current accruals (working capital accruals) rather than total accruals for the reason that current accruals are established on the association between changes in current accounts (e.g. accounts receivables, inventories and accrued expenses such as accounts payable, Income tax payables) and revenues on the income statement. Dechow (1994) found working capital accruals are essential in assisting the market determine whether there are intrinsic problems within a firm's operational cash flows.

Research has shown the regularity and importance of errors established when using balance sheet statements based on the accruals estimates can be considerable (see Hribar \& Collins, 2002). Hribar and Collins (2002) suggest how to estimate discretionary and non-discretionary accruals, and their research shows the mispricing of these accruals components. According to the definitions of working capital accruals, following the modified Jones model (1991) and the method which is developed by Teoh et al. (1998b) and articulated by Wie and Xie (2008), working capital accruals for a firm in period $t\left(A C C_{t}\right)$ are calculated as follows (Note 4):

$$
A C C_{t}=\frac{\Delta\left(A R_{t}+T I_{t}+O C A_{t}\right)-\Delta\left(A P_{t}+I T P_{t}+O C L_{t}\right)}{T A_{t-1}}
$$

Where:

$A R_{t}$ is total receivables (WS\# 02051), $T I_{t}$ is total inventory (WS\# 2101), $O C A_{t}$ is the other current assets (WS\# 2149), $A P_{t \mathrm{t}}$ is accounts payable (WS\# 3040), ITP $P_{t}$ is tax payable (WS\# 3063), $O C L_{t}$ is other current liabilities (WS\# 3066), $T A_{t-1}$ is total assets (WS\#02999) from the last period and $\Delta$ : the yearly change in a variable.

Following equation (1), normal or non-discretionary accruals are functions of allocated drivers. Those components of accruals not explained by these drivers are defined as discretionary (abnormal). In the Jones (1991) model, total accruals are formulated as a function of the change in sales and gross equipment and plant. Follow the earnings quality literature, each account is scaled by lag (previous) of total assets, Worldscope data item and date of the fiscal year-end. This paper focuses on firm profitability before financial expenses and taxes. The earnings measure used for the analysis is operating income after depreciation (before interest, taxes, and extraordinary items). Similar to other accounting earnings research, it is assumed that there is at least a fourmonth delay between the end of each firm's fiscal year and when it publishes its annual report and accounts. All firms with available accounting data were used, regardless of their fiscal yearend date.

Table 1 provides the descriptive statistics for the accounting variables used within this study. Panel 1.1 summaries statistical information on the working capital components and panel 1.2 presents statistics about cash flow, earnings and components of accruals. Accruals contain the changes in various working capital items. Within the sample, current assets are the main item, representing a median value of $49.3 \%$ of total assets. Similarly, accounts receivable and inventory are structured as a part of current assets; the median of these items are $31.3 \%$ and $16.9 \%$ respectively. Panel 1.2 illustrates information about accruals components, earnings and cash flow on the individual accrual items. The biggest changes in accrued items are the change in accounts receivables. After that, the items that contribute most to differentiating accruals are changes in inventories and other current liabilities. The standard deviation of each of above items is not less than $5.5 \%$. While changes in the level of accruals may not be remarkable, they can lead to considerable changes in corporate earnings. 
Table 1. Descriptive statistics

\begin{tabular}{|c|c|c|c|c|c|c|}
\hline & & Mean & Standard Deviation & 25th Percentile & 50th Percentile & 75th Percentile \\
\hline \multicolumn{7}{|c|}{1.1 Working capital components (scaled by average of total assets) } \\
\hline Current Assets & $C A$ & 0.509 & 0.271 & 0.300 & 0.493 & 0.693 \\
\hline Current liabilities & $C L$ & 0.374 & 0.452 & 0.185 & 0.313 & 0.471 \\
\hline Accounts receivable & $A R$ & 0.198 & 0.158 & 0.074 & 0.169 & 0.285 \\
\hline Total inventories & $T I$ & 0.093 & 0.140 & 0.001 & 0.027 & 0.143 \\
\hline Other current assets & $O C A$ & 0.036 & 0.065 & 0.004 & 0.016 & 0.039 \\
\hline Accounts payable & $A P$ & 0.073 & 0.142 & 0.000 & 0.030 & 0.103 \\
\hline Income tax payable & ITP & 0.008 & 0.030 & 0.000 & 0.000 & 0.010 \\
\hline Other current liabilities & $O C L$ & 0.226 & 0.347 & 0.079 & 0.167 & 0.301 \\
\hline \multicolumn{7}{|c|}{ 1.2 Accruals components, earnings and cash flow } \\
\hline Cash flow & $O C F$ & -0.001 & 0.316 & -0.033 & 0.058 & 0.117 \\
\hline Earning & $E A R N$ & -0.041 & 0.262 & -0.048 & 0.017 & 0.045 \\
\hline Changes in accounts receivables & $\triangle A R$ & 0.011 & 0.107 & -0.018 & 0.006 & 0.046 \\
\hline Changes in inventories & $\triangle T I$ & 0.005 & 0.055 & -0.002 & 0.000 & 0.011 \\
\hline Changes in accounts payable & $\triangle A P$ & 0.025 & 0.108 & 0.000 & 0.000 & 0.031 \\
\hline Changes in income tax payable & $\triangle I T P$ & 0.003 & 0.014 & 0.000 & 0.000 & 0.002 \\
\hline Changes in other current liabilities & $\triangle O C L$ & -0.012 & 0.478 & -0.041 & 0.001 & 0.041 \\
\hline
\end{tabular}

The sample contains all common stocks (excluding financial companies) on Worldscope and Datastream with available data. We measure items for each company of the end of April each year from 2004 to 2009. Reporting delay is assumed of four months from the end of the fiscal year. Table 1 provides summary statistics for the working capital components in panel 1.1 and Accruals components, earnings and cash flow in panel 1.2. Note, all above items are divided by average total assets. In panel 1.1, the main items of current assets which are used to calculate current accruals are presented. Panel 1.2 provides descriptive statistics for Cash flow $(O C F)$ and earnings (Earnings defined as operating income after depreciation). Also, panel 1.2 demonstrates changes in accounts receivables $(\triangle A R)$, inventories $(\triangle T I)$, accounts payable $(\triangle A P)$, income tax payable $(\triangle I T P)$ and other current liabilities $(\triangle O C L)$.

\subsection{The Magnitude of Earnings Quality}

This paper focuses on the potential significance of looking beyond the bottom-line reported earnings number and considering the level of accruals. The cross-sectional predictive authority of surprises in earnings for expected returns is widely documented in earlier research (see Latane \& Jones, Bernard \& Thomas, 1989; Chan et al., 1996). It might be helpful to compare firms with high or low surprises in earnings. As a result, changes in earnings may reflect the quality of earnings which is important. Table 2 illustrates the predictive power of earnings surprises for market returns by considering the accruals as a measure of earnings quality. Using the method outlined by Chan et al. (2006), our research regrouped stocks at the end of each year into five groups according to their level of surprise in reported earnings. The measure of earnings surprise was defined as change in earnings since a previous year relative to previous total assets. For each portfolio formation date, current year earnings was the earnings figure extracted from the most recently fiscal year (with a four-month publication delay). Simultaneously, stocks were ranked into quintile groups separately according to accruals relative to lag of total assets. The intersection of these two groups provided 25 distinct categories. This enabled the identification of the annual buy-and-hold and abnormal returns for the portfolio at the end of its first year of formation (Note $5)$.

After finding the abnormal return, the adjusted abnormal returns were calculated according to size and book-tomarket value (Note 6).

Using this analysis, five categories were created relative to firm size. At the same time, computations of the quintile split points for the portion of book-to-market value were prepared independently. The intersection of these two categories provided 25 groups. Also, buy- and-hold returns for equally weighted portfolios were computed within each group. Understanding of where a share fell relative to its size and book-to-market breaking points were used to construct control portfolios. Finally, abnormal returns was determined by calculating the difference between the original return from the return generated by the control portfolio. 
Table 2. Normal and abnormal return sorted by accruals

\begin{tabular}{|c|c|c|c|c|c|c|}
\hline \multicolumn{7}{|c|}{ 2.1. Normal Return } \\
\hline$\underline{\text { Period }}$ & $\underline{\operatorname{Low}(1)}$ & $\underline{2}$ & $\underline{3}$ & $\underline{4}$ & $\underline{\operatorname{High}(5)}$ & $\underline{l M H}$ \\
\hline 2006 & 0.827 & 0.987 & 1.023 & 1.055 & 1.193 & -0.365 \\
\hline 2007 & 0.751 & 0.936 & 0.985 & 1.015 & 1.114 & -0.363 \\
\hline 2008 & 0.497 & 0.777 & 0.875 & 0.937 & 1.032 & -0.535 \\
\hline 2009 & 0.812 & 1.017 & 1.065 & 1.135 & 1.421 & -0.609 \\
\hline \multicolumn{7}{|c|}{ 2.2 Abnormal Return } \\
\hline Period & $\underline{\operatorname{Low}(1)}$ & 2.000 & 3.000 & 4.000 & $\operatorname{High}(5)$ & $\underline{\underline{l M H}}$ \\
\hline 2006 & 0.125 & 0.176 & 0.145 & 0.280 & 0.455 & -0.330 \\
\hline 2007 & 0.065 & 0.058 & 0.065 & 0.137 & 0.310 & -0.245 \\
\hline 2008 & -0.228 & 0.003 & -0.022 & 0.066 & 0.188 & -0.416 \\
\hline 2009 & 0.168 & 0.144 & 0.326 & 0.408 & 1.027 & -0.860 \\
\hline
\end{tabular}

Note. The portfolio included all common stocks of the U.K. listed companies (excluding financial companies) on Thomson one Banker. Worldscope and Datastream data set is used with available data. At the end of April each year, stocks were sorted into five classifications by level of accruals (relative to lag of total assets). The intersection of the two sorts provides 25 groups in portfolios. Normal returns in panels 2.1 and abnormal returns in panel 2.2 are reported for each portfolio in the first year following portfolio formation. Abnormal return resulted from the excess over a control portfolio and normal return which is adjusted by size and book-to-market.

Earlier research used earnings surprise to make a prediction of stock returns. Following research of Chan et al. (2006), this study uses the marginal contribution of surprising in earnings. As a result, stocks were ranked between the top and bottom deciles according to the five categories of accruals. In Table 2, the normal return (by and hold return) and abnormal return were ranked according to the quintals. The differences between low and high return $(L M H)$ are reported in the last row of each panel. The average in normal returns was 19\% per year. According to panel 2.2, the spread in abnormal returns between the high and low quintiles by accruals averages was $19 \%$. Using earlier studies, when earnings surprise is favorable one would expect positive abnormal returns. However, in this work, abnormal returns are actually negative if accruals are high. These results demonstrate that when accruals are high then the abnormal returns are negative across all categories of earnings surprise. Alternatively, when earnings surprises remain unchanged, stock returns are turned more disappointing as accruals increase. The evidence in Table 2 suggests that the market is misled by focusing on the bottom-line earnings and ignores important earnings quality information found within the quality of earnings accruals components. These results agree with those of Collins and Hribar (2000) and Chan et al. (2006), who found that the importance of the increase in returns following significant earnings surprises depends on whether the change in earnings is accompanied by low or high level of accruals.

\subsection{The Accruals Effects on Stock Returns}

Table 3 illustrates the quality of earnings components and the returns of stocks classified by type of accrual. Stocks were ranked by accruals scaled by lag of total assets at the end of April each year. They were then allocated to one of 10 equal-sized portfolios. Annual normal returns and abnormal returns were considered for these equally weighted decile portfolios for each of the three years following portfolio formation. Panel 3.1 of Table 3 shows the average levels of cash flows $(C F)$, earnings (EBIT), accruals $(A C C)$ and accrual components (e.g. accounts receivables) for the decile portfolios which are measured as the portfolio formation date. In this portfolio the upper ranked stocks, accruals averaged 0.008 of total assets, while in the bottom of portfolio, accruals were -0.008 of total assets. Earnings relative to total assets in the portfolio of the highest-ranked was 0.001 but only -0.183 for the bottom deciles of the portfolio.

According to the Panel 3.1, firms with the highest positive earnings created 0.160 cash flow levels because of high level of accruals. In contrast, firms located in the bottom decile of the portfolio created considerable cash flows of 0.451 in spite of their low amount of earnings due to their negative accruals. Within Panel 3.1 of Table 3 , firms with high level of accruals had a tendency to be growth stocks with low book-to-market $(B M)$ ratios; the book-to-market ratio for top deciles was 0.397 . Meanwhile, sales growth averaged $2.029 \%$ yearly in the two years according to top deciles of portfolio formation. Panels 3.3 and 3.4 in Table 3 presents evidence about the better past performance of firms, ranked by accruals). The average return for this group is 1.576 per year over the two prior years, and previous abnormal returns were high. Conversely, the unexpected past stock price reaction was motivated by the large returns in the year before portfolio formation. The returns during the prior year to portfolio formation were above average. The portfolio also shows that a firm's performance suffers from a 
relative slowdown and it is consistent with the idea that managers may manipulate earnings to continue positive investor response. Additionally, the aggressive valuations of firms with large positive accruals present managers with an added motivation to control earnings in order to continue earnings growth and avoid negative earnings surprises.

Jegadeesh and Titman (1993); Chan et al. (1996) and Chan et al. (2006) suggest a continuation of price reactions over intermediate horizons. The above-average previous returns of the portfolio with high level of accruals suggest that returns should continue to be comparatively high in the year following portfolio formation. Chan et al. (2006) show that during the first year of the post formation date, $41.9 \%$ is the average return within top decile portfolio. Their study shows an average return of $11.3 \%$ for the bottom deciles of their portfolio, with a return differential between the low- and high-accruals portfolios of $28.9 \%$.

Panel 3.3 of Table 3 analyses portfolio returns by size and book-to-market ratio effects. Average abnormal returns differ by $7.4 \%$ between the low- and high-accruals portfolios in the first post formation year. This difference is mainly caused because of the low abnormal return on the high-accruals portfolio (36.3\%) and the abnormal return for the low-accrual portfolio is comparatively small (11.6\%). The gap in abnormal returns across the excessive decile portfolios may stem from differences in managerial motivation to manage earnings. Accordingly, if managers do manipulate earnings, it is expected that they would inflate earnings instead of either reducing or smoothing earnings. Finally, the impact of managing stock returns is more evident in the portfolio that includes high positive levels of accruals. As result, accruals has a power to predict future returns, even though the result is mainly determined by the poor performance of the portfolio with high levels of accruals, where the motivation to manage earnings may be strongest.

Table 3. Portfolio sorted by accruals

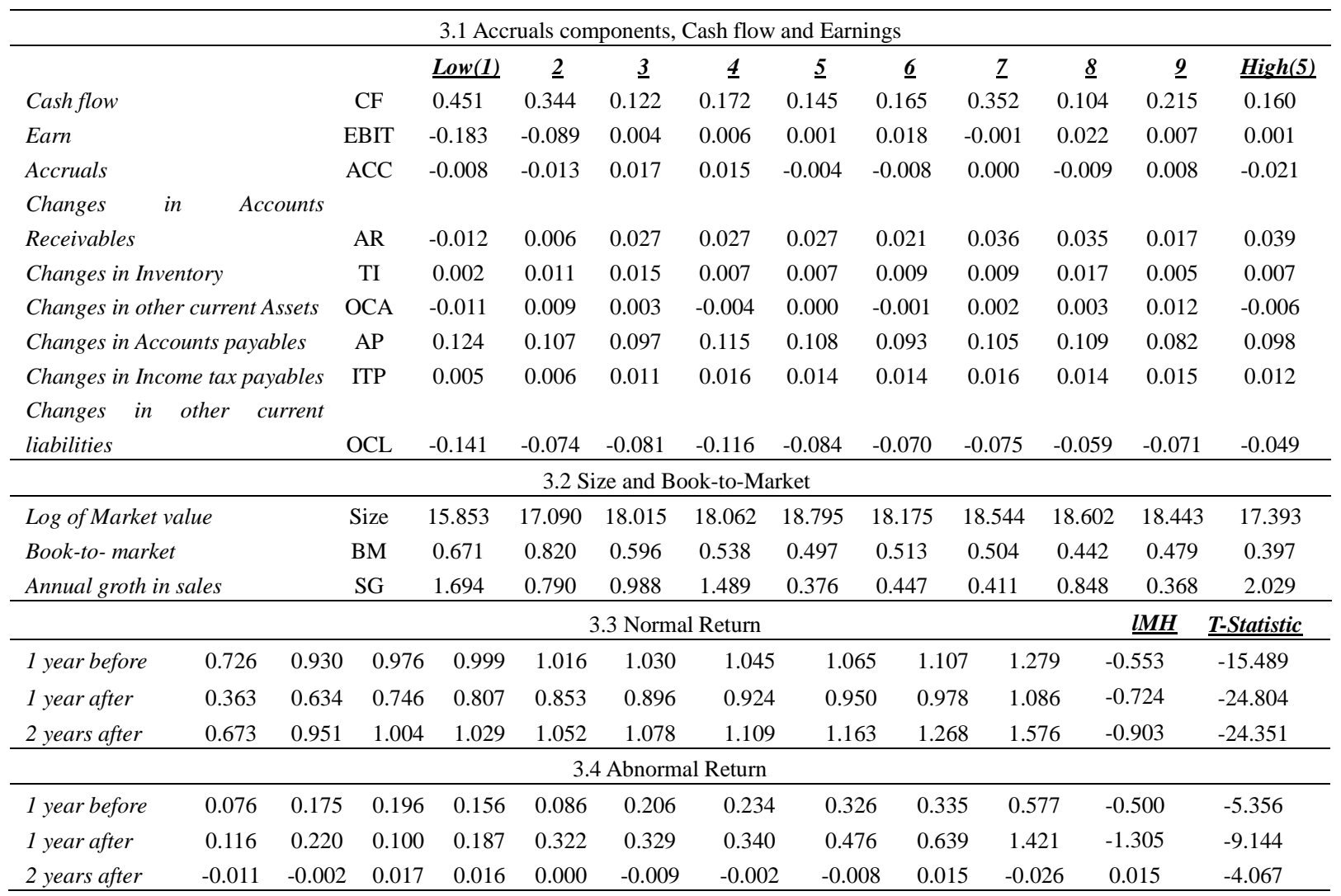

Table 3 demonstrates the summary statistics for deciles of data sorted by accruals. The sample contained all domestic common stocks (excluding financial companies) on Worldscop and Datastream that had usable data. At the end of April each year from 2004 to 2009, all stocks were ranked by accruals relative to average of the total assets and divided to one of 10 equally weighted portfolios. Average values of Cash flow, earnings before Interest and Tax, accruals, and changes in Accounts receivable, Inventory, Other current assets, Accounts payable, Income tax payable and other current Liabilities are presented in Panel 3.1. All the items in Panel 3.1 
are divided by average total assets of firms. Note, this table shows the characteristics of means of companies at ten levels. First decile (as lowest deciles) is the bottom of the portfolio, and the tenth decile is the upper decile. Panel 3.2 reports average annual returns in excess of the return on control portfolios matched by size is the natural logarithm of market value of equity and book-to-market value is computed as ratio of Book value to Market value of stock. Average annual sales growth was computed over the previous two years.

Average annual normal (by and hold returns) and abnormal returns are presented in panel 3.3. and 3.4 for each year from one year prior to portfolio formation to two years after formation, along with the difference between the bottom and top deciles and the $T$-statistic for the mean difference.

\section{Predictive Power of Accruals Components}

Each of the accruals components provide information about a firm's operating activities and the market should respond to this information accordingly. As was discussed earlier, changes in current assets and liabilities may be employed by security market analysts as an indicator of prospects for a business. Chan et al. (1996) provide evidence that the information content provided by accruals components may even delay the market's response to information contained within a reported earnings number.

Linking total accruals to future returns presents limited opportunity to identify an explanation for the predictive power of accruals. In a similar manner to earlier work by Thomas and Zhang (2002) and Chan et al. (2006), this research focused on the individual components of accruals rather than total accruals. Chan et al. argue that as certain accrual accounts are more open to manipulation than others, the association between accruals and future returns should focus on these accounts. They demonstrate that if the market response to a decline in sales growth is forceful, after that the results of the slowdown might be comparatively uniform across the accruals components. Also, an increase in one component of current liabilities may send an early warning sign of deterioration in cash flow and for this reason may signal poor share price performance in the future.

Assuming that accruals changes cannot be manipulated, an increase in accounts payable lowers current accruals and is distinguished as transferring present earnings to the future. Therefore, investors understand and interpret this event as a negative alarm to firm's earnings and do not distinguish the effect on future income. Table 4 provides normal (buy and hold returns) and abnormal returns on portfolios which are sorted by each component of accruals separately. Each component consistently shows normal and abnormal returns in the first year following portfolio formation date. The accruals components are related to the main increase in returns over the post formation period which is also related to changes in inventory (see panel 4.2). The mean normal return over the first post formation year for the highest portfolio ranked was $80.4 \%$ and for lowest was $92 \%$. The panel shows average abnormal returns for the first post formation year of $1.2 \%$. These results are similar to those contained in Table 2, which focuses total accruals. In table 2, the amount of normal and abnormal return in bottom quintal for year 2006 are $82.7 \%$ and $1.25 \%$ respectively. Thomas and Zhang (2002) found a strong relationship between changes in inventory and expected returns, with changes in inventories indicating unexpected changes in future view of the firm. As an example, changes in total inventory in various macroeconomic models provide a negative signal of future economic conditions. Alternatively, obsolete inventories items may not be fully written-off obsolete by managers, or they perhaps allocate more overhead expenses to inventory when calculating the cost of goods sold. Panel 3.2 of Table 4 illustrates those changes in accounts receivable during the second year after portfolio formation date result in average normal returns of $107 \%$ and $31.8 \%$ for abnormal returns. Other researchers suggest that overstating sales or recognizing revenues in advance is a widely used method of earnings manipulation (Note 7).

Also, it is possible that the increases in total accounts receivable may result from offering increased credit terms in an effort to preserve revenue growth.

Panel 3.4.4 shows normal and abnormal returns ranked by changes in accounts payable. The change in accounts payable presents a way to distinguish the deciles portfolios' prospect performance. Such a change does not engage with the conservative concept that identifies accruals with manager manipulation. According to panel 4.4 the top deciles portfolio's normal returns during the second post formation year is $110.2 \%$ and its abnormal return is $39.2 \%$. Changes in accounts payable illustrate the positive association in returns between the low and top high portfolios. For example, when a company's business prospects are fine then an increase in accounts payable may be expected for the reason that the firm could not be as cash-rich as before. Inventory changes are the main accruals component to predicting returns. 
Table 4. Portfolio sorted by accruals components

\begin{tabular}{|c|c|c|c|c|c|c|c|c|c|c|c|c|c|}
\hline & & $\underline{\operatorname{Low}(1)}$ & $\underline{2}$ & $\underline{3}$ & $\underline{4}$ & $\underline{5}$ & $\underline{6}$ & $\underline{7}$ & $\underline{8}$ & $\underline{9}$ & $\underline{\operatorname{High}(10)}$ & $\underline{L M H}$ & $\underline{\text { T-statistic }}$ \\
\hline \multicolumn{14}{|c|}{ 4.1Ranked by changed in Accounts receivables } \\
\hline \multicolumn{14}{|l|}{ Normal } \\
\hline Return & $R \_1$ & 0.815 & 0.795 & 0.772 & 0.731 & 0.811 & 0.853 & 0.802 & 0.872 & 0.884 & 0.916 & -0.101 & -3.399 \\
\hline \multicolumn{14}{|l|}{ Normal } \\
\hline Return & $R \_2$ & 1.112 & 1.079 & 1.081 & 1.074 & 1.059 & 1.123 & 1.113 & 1.095 & 1.093 & 1.079 & 0.033 & 1.362 \\
\hline \multicolumn{14}{|l|}{ Abnormal } \\
\hline Return & $A B R \_1$ & -0.064 & 0.006 & -0.057 & 0.031 & 0.139 & 0.039 & 0.012 & -0.015 & 0.006 & -0.051 & -0.013 & -0.313 \\
\hline \multicolumn{14}{|l|}{ Abnormal } \\
\hline Return & $A B R \_2$ & 0.307 & 0.310 & 0.387 & 0.334 & 0.361 & 0.487 & 0.772 & 0.524 & 0.249 & 0.318 & -0.011 & -0.173 \\
\hline \multicolumn{14}{|c|}{ 4.2 Ranked by changed in Accounts Inventories } \\
\hline \multicolumn{14}{|l|}{ Normal } \\
\hline Return & $R \_1$ & 0.804 & 0.772 & 0.816 & 0.000 & 0.742 & 0.782 & 0.843 & 0.840 & 0.863 & 0.920 & -0.117 & -4.116 \\
\hline \multicolumn{14}{|l|}{ Normal } \\
\hline Return & $R \_2$ & 1.109 & 1.054 & 1.069 & 1.075 & 1.111 & 1.172 & 1.073 & 1.101 & 1.083 & 0.098 & 1.011 & 1.124 \\
\hline \multicolumn{14}{|l|}{ Abnormal } \\
\hline Return & $A B R \_1$ & -0.066 & 0.003 & 0.056 & 0.062 & -0.001 & -0.011 & -0.019 & 0.019 & -0.047 & 0.012 & -0.078 & -0.422 \\
\hline \multicolumn{14}{|l|}{ Abnormal } \\
\hline Return & $A B R \_2$ & 0.311 & 0.266 & 0.337 & 0.420 & 0.497 & 0.000 & 2.227 & 0.306 & 0.370 & 0.264 & 0.047 & 0.765 \\
\hline \multicolumn{14}{|c|}{4.3 Ranked by changed in other current assets } \\
\hline \multicolumn{14}{|l|}{ Normal } \\
\hline Return & $R \_1$ & 0.870 & 0.836 & 0.811 & 0.772 & 0.000 & 0.727 & 0.864 & 0.839 & 0.853 & 0.881 & -0.011 & -0.356 \\
\hline \multicolumn{14}{|l|}{ Normal } \\
\hline Return & $R \_2$ & 1.073 & 1.093 & 1.065 & 1.107 & 0.000 & 0.000 & 1.079 & 1.096 & 1.090 & 1.082 & -0.009 & -0.284 \\
\hline \multicolumn{14}{|l|}{ Abnormal } \\
\hline Return & $A B R \_1$ & -0.035 & -0.006 & -0.044 & 0.037 & 0.000 & -0.072 & 0.075 & 0.001 & 0.038 & -0.037 & 0.002 & 0.030 \\
\hline \multicolumn{14}{|l|}{ Abnormal } \\
\hline Return & $A B R \_2$ & 0.403 & 0.271 & 0.317 & 0.526 & 0.000 & 0.000 & 0.403 & 0.313 & 0.384 & 0.337 & 0.066 & 0.421 \\
\hline & & & & & 4 Rank & by chan & in Acco & ts payab & & & & & \\
\hline Normal & & & & & & & & & & & & & \\
\hline Return & $R \_1$ & 0.807 & 0.796 & 0.773 & 0.784 & 0.756 & 0.804 & 0.874 & 0.846 & 0.881 & 0.927 & -0.120 & -4.133 \\
\hline Normal & & & & & & & & & & & & & \\
\hline Return & $R \_2$ & 1.079 & 1.078 & 1.093 & 1.074 & 1.100 & 1.107 & 1.122 & 1.068 & 1.085 & 1.102 & -0.023 & -0.884 \\
\hline Abnormal & & & & & & & & & & & & & \\
\hline Return & $A B R \_1$ & -0.097 & -0.029 & -0.008 & 0.109 & 0.042 & 0.043 & -0.032 & 0.046 & 0.022 & -0.046 & -0.051 & -1.237 \\
\hline Abnormal & & & & & & & & & & & & & \\
\hline Return & $A B R \_2$ & 0.275 & 0.285 & 0.433 & 0.380 & 0.362 & 0.795 & 0.427 & 0.348 & 0.351 & 0.392 & -0.117 & -1.755 \\
\hline & & & & & 5 Ranke & y chang & in Incon & ax payal & & & & & \\
\hline Normal & & & & & & & & & & & & & \\
\hline Return & $R \_1$ & 0.883 & 0.817 & 0.749 & 0.000 & 0.000 & 0.686 & 0.859 & 0.867 & 0.913 & 0.931 & -0.048 & -2.916 \\
\hline Normal & & & & & & & & & & & & & \\
\hline Return & $R \_2$ & 1.076 & 1.073 & 1.086 & 1.109 & 0.000 & 0.000 & 1.062 & 1.088 & 1.086 & 1.079 & -0.003 & -0.162 \\
\hline Abnormal & & & & & & & & & & & & & \\
\hline Return & $A B R \_1$ & -0.026 & -0.026 & 0.014 & 0.000 & 0.000 & -0.072 & 0.062 & 0.000 & 0.028 & -0.021 & -0.005 & -0.130 \\
\hline Abnormal & & & & & & & & & & & & & \\
\hline Return & $A B R \_2$ & 0.307 & 0.293 & 0.373 & 0.601 & 0.000 & 0.000 & 0.340 & 0.271 & 0.274 & 0.229 & 0.077 & 1.343 \\
\hline & & & & 4.6 & Ranked & changed & other cl & ent liabil & ties & & & & \\
\hline Normal & & & & & & & & & & & & & \\
\hline Return & $R \_1$ & 0.862 & 0.836 & 0.771 & 0.773 & 0.739 & 0.785 & 0.889 & 0.795 & 0.887 & 0.911 & -0.049 & 1.343 \\
\hline Normal & & & & & & & & & & & & & \\
\hline Return & $R \_2$ & 1.073 & 1.050 & 1.038 & 1.081 & 1.054 & 1.153 & 1.167 & 1.090 & 1.124 & 1.078 & -0.005 & -0.225 \\
\hline Abnormal & & & & & & & & & & & & & \\
\hline Return & $A B R \_1$ & -0.081 & 0.019 & -0.026 & 0.045 & 0.067 & 0.054 & 0.057 & -0.059 & 0.029 & -0.057 & -0.023 & -0.683 \\
\hline Abnormal & & & & & & & & & & & & & \\
\hline Return & $A B R \_2$ & 0.290 & 0.225 & 0.445 & 0.656 & 0.406 & 0.581 & 0.526 & 0.306 & 0.375 & 0.237 & 0.053 & 0.948 \\
\hline
\end{tabular}

Note. The sample contains all domestic common stocks (excluding financial companies) on Worldscope and Datastream with available data. At the end of April each year from 2004 to 2009, all shares were ranked by accruals relative to average of the total assets and divided to one 
of 10 equally weighted portfolios. Annual normal returns (buy-and-hold returns) are computed over the subsequent year, with returns in excess of the return on a portfolio matched by size and book-to-market which is already explained. Average returns in each of the first to second years following portfolio formation $\left(R \_l\right.$ and $R \_2$ respectively) and surplus stock returns in each of the first to second post formation years $\left(A B R \_1\right.$ and $\left.A B R \_2\right)$ on the equally weighted decile portfolios are provided in Table 4. Also, the differences between the bottom and top decile portfolios are described as $L M H$ and the $T$-Statistic for the mean difference.

\subsection{Discretionary and Non-Discretionary Accruals}

Within the literature the discretionary portion of accruals reflects management choice, while the nondiscretionary components of accruals capture the impact of business conditions. Adjusting for the effects of business conditions helps to identify the role of management discretion in the use of accruals for managing earnings.

Normal or nondiscretionary accruals are functions of allocated factors or drivers. The components of accruals not explained by these factors are defined as discretionary. As mentioned in section 3.1, total accruals are defined as the change in revenue and gross property, plant and equipment by Jones (1991). As most long-term accruals, such as depreciation, are unlikely to be an efficient means of managing earnings because of their visibility (see Gore et al., 2002), this paper focuses on discretionary current accruals. For computing the discretionary current accruals for firm $i$ in the year $t$ we follow the following equation from Teoh et al., (1998a) (Note 8):

$$
A C C_{t}=\alpha_{1} \frac{1}{T A_{(t-1+t) / 2}}+\alpha_{2} \frac{\Delta S A_{t}-\Delta A R_{t}}{T A_{(t-1+t) / 2}}+\varepsilon_{\mathrm{t}}
$$

Where: $A C C_{t}$ is total current accrual for firm $i$ and year $t ; \Delta S A_{t}$ is change in Sales (WS\#01001) for the year period; $\triangle A R_{t}$ is accounts receivable (WS\#02051) and $T A_{(t-1+t) / 2}$ is average of total assets from the previous and current years (Note 9).

Therefore, discretionary total current accruals are calculated as follows:

$$
D_{t} A C C_{t}=\varepsilon_{t}
$$

The non-discretionary accruals are computed by:

$$
N D A C C_{t}=A C C_{t}-D A C C_{t}
$$

In equation (2), the level of working capital accruals are modeled as a relatively steady portion of firm sales. This equation formulates the idea that current accruals requirements are strongly related to sales. Temporary changes in this association are smoothed out by estimating the ratio of affecting average of the pervious and current years to sales. The discretionary accruals from the change in a working capital are defined as the difference between the real level and its computed level from the equation.

In Table 5, the stocks were sorted into decile portfolios by discretionary and nondiscretionary accruals in panels 5.1 and 5.2 respectively. When sorted by discretionary accruals, the difference in returns between the low and top deciles of ranked portfolios comes close to matching the performance when portfolios are sorted by total accruals. In panel 5.1, the return for the highest (extreme) decile is $78.2 \%$ for normal returns (1.8\% for abnormal returns) over the first post- formation date. In each year, changes in working capital accruals are expected to include management discretion. Therefore the extreme portfolios which is sorted by discretionary accruals to be assumed to discover the force of manipulation. Earlier research shows that methods for separating accruals commonly used in the accounting literature are inadequate for separating discretionary and nondiscretionary accruals (see Guay et al., 1996). As a result, the ability of calculated discretionary accruals to predict returns is understated. However, the result of this paper is expected to overemphasis the capacity of nondiscretionary accruals to create returns. Although, the results in panel 5.2 suggest that there is significant association between

\begin{tabular}{|c|c|c|c|c|c|c|c|c|c|c|c|c|c|}
\hline & & $\underline{\operatorname{Low}(1)}$ & $\underline{2}$ & $\underline{3}$ & $\underline{4}$ & $\underline{5}$ & $\underline{6}$ & $\underline{7}$ & $\underline{8}$ & $\underline{9}$ & $\underline{\operatorname{High}(5)}$ & $\underline{\underline{L M H}}$ & $\underline{\underline{T \text {-statistic }}}$ \\
\hline \multicolumn{14}{|c|}{ 5.1 Discretionary Accruals } \\
\hline Normal Return & $R \_1$ & 0.775 & 0.825 & 0.835 & 0.809 & 0.839 & 0.840 & 0.824 & 0.870 & 0.840 & 0.782 & -0.007 & -0.200 \\
\hline Normal Return & $R \_2$ & 1.090 & 1.087 & 1.095 & 1.114 & 1.106 & 1.124 & 1.105 & 1.092 & 1.050 & 1.049 & 0.041 & 0.769 \\
\hline Abnormal Return & $A B R \_1$ & -0.025 & 0.024 & -0.063 & 0.024 & 0.057 & -0.013 & -0.048 & 0.040 & 0.021 & 0.018 & -0.044 & -0.586 \\
\hline Abnormal Return & $A B R \_2$ & 0.512 & 0.378 & 0.396 & 0.344 & 0.340 & 0.391 & 0.352 & 0.489 & 0.302 & 0.591 & -0.079 & -0.245 \\
\hline
\end{tabular}
nondiscretionary accruals and future returns.

Table 5. Portfolio sorted by discretionary and nondiscretionary accruals 


\begin{tabular}{llllllllllllllr}
\hline \multicolumn{11}{c}{ 5.2 Nondiscretionary Accruals } \\
\hline Normal Return & $R \_1$ & 0.882 & 0.860 & 0.874 & 0.894 & 0.813 & 0.826 & 0.806 & 0.781 & 0.791 & 0.712 & -0.044 & 5.244 \\
Normal Return & $R \_2$ & 1.116 & 1.123 & 1.093 & 1.071 & 1.050 & 1.123 & 1.039 & 1.104 & 1.102 & 1.093 & 0.022 & 0.480 \\
Abnormal Return & $A B R \_1$ & 0.126 & -0.024 & -0.071 & 0.021 & -0.034 & -0.017 & -0.052 & 0.000 & 0.052 & 0.035 & 0.090 & 1.204 \\
Abnormal Return & ABR_2 & 0.346 & 0.371 & 0.333 & 0.287 & 0.263 & 0.464 & 0.282 & 0.533 & 0.458 & 0.762 & -0.416 & -1.322 \\
\hline
\end{tabular}

The sample contains all domestic common stocks (excluding financial companies) on Worldscope and Datastream with available data. At the end of April each year from 2004 to 2009, all stocks were ranked by accruals which are scaled by average of the total assets and divided to one of 10 equally weighted portfolios. Annual normal returns (buy-and-hold returns) are computed over the subsequent year, with returns in excess of the return on a portfolio matched discretionary and nondiscretionary accruals. Average returns in each of the first to second years following portfolio formation $\left(R_{-} l\right.$ and $R_{-} 2$ respectively) and surplus stock returns in each of the first to second post formation years $\left(A B R_{-} 1\right.$ and $\left.A B R \_2\right)$ on the equally weighted decile portfolios are provided in Table 5. Also, the difference between the bottom and top decile portfolios is provided as $L M H$ and the $T$ Statistic for the mean difference.

Table 6 shows the results of analyzing discretionary accruals. The table explains how the discretionary accruals equation was estimated to provide the discretionary accruals variable. Table 6 shows the coefficient as the inverse lag total assets FTA (calculated as $\left.1 / T A_{(t-1+t) / 2}\right)$ in equation is positive $(94709.600$, t-statistic $=7.390$, $\mathrm{p}$-value $<0.001)$. The coefficient on change in sales $(S T A)$ was negative and significant $(-0.088$, $\mathrm{t}$-statistic $=-$ 6.440, p-value <0.001) which is consistent with the research of Teoh et al. (1998). The Adj R-squared for equation is $25.1 \%$ compared with the Adj R-squared of $27 \%$ found by Teoh et al. (1998).

Table 6. The estimation of the discretionary accruals equation to create the discretionary accruals variable

\begin{tabular}{llrr}
\hline & Variables & $\underline{\text { Coeff. }}$ & $\underline{\text { t-stat }}$ \\
\hline Intercept & Intercept & -0.007 & -0.870 \\
& & & 0.382 \\
Inverse average total assets & FTA & 94709.600 & 7.390 \\
& & & $<0.001$ \\
Change in sales & STA & -0.088 & -6.440 \\
& & & $<0.001$ \\
\hline Number of observation & & 3779 & \\
Adj $R$-squared & & $25.10 \%$ & \\
\hline
\end{tabular}

Note. According to equation (2) the regression analysis runs base under linear function as follows;

$$
A C C_{t}=\alpha_{1} \frac{1}{T A_{(t-1+t) / 2}}+\alpha_{2} \frac{\Delta S A_{t}-\Delta A R_{t}}{T A_{(t-1+t) / 2}}+\varepsilon_{\mathrm{t}}
$$

Where $A C C_{t}$ is total current accruals for firm i and year t, $\triangle S A_{\mathrm{t}}$ is the change in total sales (WS \# 01001) for year and $A R_{t}$ is the total assets for the year, and $T A_{(t-1+t) / 2}$ is the average of total assets from the current and previous year, $A R_{t}^{i}$ is the total accounts receivable (WS\#02051). Thus, discretionary current accruals are computed as follows: $D A C C_{\mathrm{t}}$, the differences between discretionary accruals and current accruals which is defined as result will be taken from nondiscretionary accruals. FTA is calculated as $1 / T A_{(t-1+t) / 2}$ and $S T A$ is demonstrated as $\triangle S A_{t}$ $\triangle A R_{t} / T A_{(t-1+t) / 2}$.

\section{Summary and Conclusion}

Within the academic literature, the consensus view is that investors and analysts have traditionally focused on reported 'bottom-line' reported measures of income and typically ignored the decision-relevant information contained with other financial statement items and disclosures. Although, 'bottom-line' income has important information content, it cannot provide information about the quality of these earnings. Earnings quality is an important predictor of a firm's future returns and is heavily influenced by the use of discretionary and nondiscretionary accruals by management.

Existing empirical accounting research has found a negative relationship between accruals and future stock returns. Accruals play an important role in linking earnings surprises and returns. Increases in reported earnings that are accompanied by high levels of accruals possibly should provide information about the level of earnings quality. This present study builds on earlier work by Sloan (1996), Xie (2001) and Chan et al. (2006) and provides empirical evidence using U.K. data that shows that accruals are associated with, and can also predict, returns. 
Using a unique process for separating accruals into discretionary and nondiscretionary components, the link between accruals and operating performance is explored in years in which accruals rise significantly. This paper provides an empirical model of accruals components to investigate their link with future returns. The results suggest that working capital accruals, such as changes in accounts receivables and inventory, appear to contain important information about the earnings quality of firms and can help to predict the of future returns.

In the absence of earnings manipulation by management, information about accruals appears to provide important indicators about changes in a firm's business prospects. From our analysis it appears that a substantial increase in accruals marks a turning point in the wealth of a firm. Where a company reports a rapid increase in accruals following high stock returns and earnings growth in previous years, the company appears to suffer and its growth rate goes back to a more normal rate. Its earnings in following years would stay positive but fall along with its stock price. The year of high accruals appears to provide a signal that the firm's past growth rate cannot be sustained. Thus, firms with high level of accruals may provide warning signs about a cooling in their corporate growth. While the use of creative accounting and earnings manipulation by management could delay exposure of this bad news, it must eventually be revealed. The results of our analysis also suggest that the outcome from increased levels of accruals is not exclusively determined by changing in business conditions. Each accruals component appears to have a different degree of power for predicting returns. When accruals is separated into discretionary and nondiscretionary components, the discretionary component is the main provider of the predictability in returns.

\section{References}

Abarbanell, J., \& Bushee, B. (1998). Abnormal returns to a fundamental analysis strategy. Accounting Review, 73(2), 19-45.

Acker, D. E., \& Duck, N. W. (2007). Reference-day risk and the use of monthly returns data. Journal of Accounting, Auditing and Finance, 22(4), 527-557.

Ball, R., \& Brown, P. (1968). An empirical evaluation of accounting income numbers. Journal of Accounting Research, 6(2), 159-178. http://dx.doi.org/10.2307/2490232

Barberis, N., \& Thaler, R. (2002). A survey of behavioral finance. Working Paper No: 9222, National Bureau of Economic Research, Cambridge, MA. http://dx.doi.org/10.3386/w9222

Barth, M., Beaver, W., \& Landsman, W. (2001). The relevance of the value relevance literature for financial accounting standard setting: Another view. Journal of Accounting and Economics, 31(1), 77-104. http://dx.doi.org/10.1016/S0165-4101(01)00019-2

Basu, S. (1977). Investment performance of common stocks in relation to their price earnings ratios: A test of the efficient market hypothesis. Journal of Financial Economics, 32, 663-682. http://dx.doi.org/10.1111/j.15406261.1977.tb01979.x

Bernard, V., \& Thomas, J. (1989). Post-earnings-announcement drift: Delayed price response or risk premium?' Journal of Accounting Research, 27(1), 1-36. http://dx.doi.org/10.2307/2491062

Chan, K., Chan, L. K. C., Jegadeesh, N., \& Lakonishok, J. (2006). Earnings quality and stock returns. Journal of Business, 79(3), 1041-1082. http://dx.doi.org/10.1086/500669

Chan, L. K. C., Jason, K., \& Josef, L. (2003). The level and persistence of growth rates. Journal of Finance, 58, 643-684. http://dx.doi.org/10.1111/1540-6261.00540

Chan, L., Jegadeesh, N., \& Lakonishok, J. (1996). Momentum strategies. Journal of Finance, 51(5), 1681-1713. http://dx.doi.org/10.1111/j.1540-6261.1996.tb05222.x

Collins, D., \& Hribar, P. (2000). The market pricing of components of accruals (Unpublished manuscript). Cornell University.

Crabtree, A. D., \& Maher, J. J. (2005). Earnings predictability, bond ratings, and bond yields. Review of Quantitative Finance and Accounting, 25(3). http://dx.doi.org/10.1007/s11156-005-4766-2

Dechow, P. M., Sloan, R. G., \& Sweeney, A. P. (1995). Detecting earnings management. Accounting Review, 70(2), 193-225.

Dechow, P., Kothari, S. P., \& Watts, R. L. (1998). The relation between earnings and cash flows. Journal of Accounting \& Economics, 25(2), 131-214. http://dx.doi.org/10.1016/S0165-4101(98)00020-2

Demski, J. S. (1998). Performance measure manipulation. Contemporary Accounting Research, 15(3), 261-285. http://dx.doi.org/10.1111/j.1911-3846.1998.tb00560.x 
Fama, E. F., \& French, K. R. (1992). The cross-section of expected stock returns. Journal of Finance, 47(2), 427-466. http://dx.doi.org/10.1111/j.1540-6261.1992.tb04398.x

Francis, J. R., LaFond, P., Olsson, M., \& Schipper, K. (2004). Costs of equity and earnings attributes. Accounting Review, 79(4). http://dx.doi.org/10.2308/accr.2004.79.4.967

Gore, P., Pope, P., \& Singh, A. (2002). Earnings management and the distribution of earnings relative to targets: UK evidence. Working paper.

Guay, W., \& Verrecchia, R. (2006). Discussion of an economic framework for conservative accounting and Bushman and Piotroski. Journal of Accounting and Economic, 42(1-2), 149-165. http://dx.doi.org/10.1016/j.jacceco.2006.03.003

Guay, W., Kothari, S. P., \& Watts, R. (1996). A market-based evaluation of discretionary accrual models. Journal of Accounting Research, 34(suppl.), 83-115. http://dx.doi.org/10.2307/2491427

Healy, P. M., \& Wahlen, J. M. (1999). A review of the earnings management literature and its implications for standard setting. Accounting Horizons, 13(4), 365-383. http://dx.doi.org/10.2308/acch.1999.13.4.365

Hirshleifer, D. (2001). Investor psychology and asset pricing. Journal of Finance, 56, 1533-1597. http://dx.doi.org/10.1111/0022-1082.00379

Hribar, P., \& Collins, D. (2002). Errors in estimating accruals: Implications for empirical research. Journal of Accounting Research, 40(1), 105-134. http://dx.doi.org/10.1111/1475-679X.00041

Imhoff, E. A., \& Gerald, J. L. (1992). The effect of ex ante earnings uncertainty on earnings response coefficients. The Accounting Review, 67(2).

Jegadeesh, N., \& Titman, S. (1993). Returns to buying winners and selling losers: Implications for stock market. Journal of Finance, 48(1), 65-91. http://dx.doi.org/10.1111/j.1540-6261.1993.tb04702.x

Jones, J. (1991). Earnings management during efficiency' import relief investigations. Journal of Accounting Research, 29(2), 193-228. http://dx.doi.org/10.2307/2491047

Kothari, S. P. (2001). Capital markets research in accounting. Journal of Accounting and Economics, 31(1-3). http://dx.doi.org/10.1016/S0165-4101(01)00030-1

Lev, B., \& Nissim, D. (2006). The persistence of accruals anomaly. Contemporary Accounting Research, 23(1). http://dx.doi.org/10.1506/C6WA-Y05N-0038-CXTB

Liu, W., \& Strong, N. (2008). Biases in decomposing holding period portfolio returns. Review of Financial Studies, 21(5), 2243-2274. http://dx.doi.org/10.1093/rfs/hhl034

Piotroski, J. D. (2000). Value investing: The use of historical financial statement information to separate winners from losers. Journal of Accounting Research, 38(suppl.), 1-41. http://dx.doi.org/10.2307/2672906

Schipper, K. (1989). Commentary on earnings management. Accounting Horizons, 3, 91.

Schipper, K., \& Vincent, L. (2003). Earnings quality. Accounting Horizons, 17(Suppl.). http://dx.doi.org/10.2308/acch.2003.17.s-1.97

Scott, W. R. (2003). Financial accounting theory. Prentice Hall.

Siegel, J. G. (1991). How to analyze businesses, financial statements, and the quality of earnings. Prentice Hall.

Sloan, R. G. (1996). Do stock prices fully reflect information in accruals and cash flows about future earnings? Accounting Review, 71(3), 289-315.

Subramanyam, K. R. (1996). The pricing of discretionary accruals. Journal of Accounting and Economics, 22(13), 249-328. http://dx.doi.org/10.1016/S0165-4101(96)00434-X

Teoh, S. H., Welch, I., \& Wong, T. J .(1998). Earnings management and the long-run performance of initial public offerings. Journal of Finance, 53(6), 1935-1974. http://dx.doi.org/10.1111/0022-1082.00079

Thomas, J. K., \& Zhang, H. (2002). Inventory changes and future returns. Review of Accounting Studies, 7(2), 163-187. http://dx.doi.org/10.1023/A:1020221918065

Xie, H. (2001). The mispricing of abnormal accruals. The Accounting Review, 76(3), 357-373. http://dx.doi.org/10.2308/accr.2001.76.3.357 


\section{Notes}

Note 1. More information for these phenomena have been documented recently in some researches on behavioral finance (see Hirshleifer, 2001; and Barberis \& Thaler, 2002).

Note 2. Jones (1991) provides a model to explain the role of both discretionary and nondiscretionary accruals. Subramanyam (1996) and Xie (2001) demonstrate that discretionary component of accruals can predict the future returns, while the nondiscretionary component of accruals does not.

Note 3. In this paper, we follow the methodology from Teoh et al. (1998b) to measure the current accruals.

Note 4. In earlier research there were concerns about measuring accruals via changes in balance sheet components. The change in balance sheet accounts is introduced by measurement error into total accruals, mainly as a result of mergers, acquisitions and discontinued operations. Collins and Hribar (1999) argue that the error in total accruals introduced by the Jones (1991) model, measured through the balance sheet statement approach, is not likely to be correlated with the supposed drivers of accruals. Collins and Hribar demonstrate that the resulting measurement error is captured completely by the residual (discretionary) accruals estimate.

Note 5. Many papers use the Return Index from the Datastream data set as an indicator for calculating firm returns. For instance, Acker and Duck (2007) compute the natural logarithm of returns as follows; $\operatorname{Ln}\left[R I_{J, t+1} /\right.$ $\left.R I_{J, t}\right]$, where $R I_{J, t}$ is the Return Index of the firm base on Datastream at the close of reference day $\mathrm{J}(\mathrm{J}=1,2, \ldots$, 28) in year $t$, and $R I_{J, t+1}$ is the return index on the same reference day to close the following year. Following Acker and Duck, we calculate the return from Return Index.

Note 6. Size is defined as the natural logarithm of market capitalization (Worldscope\#08001) at the year-end, and book-to-market value is computed as portion of common equity (Worldscope\#03501) to- market capitalization at the year-end.

Note 7. SEC (2003) shows that when enforcement action is undertaken, inappropriate revenue recognition leads to promoted accounts receivable, the most frequently used method for inflating accounting earnings.

Note 8. Teoh et al. (1998a) subtract the increase in trade receivables from the change in sales when calculating discretionary accruals to allow for the possibility of credit sales manipulation by the issuer. As an example, they show by allowing generous credit policies to achieve high revenue prior to the offering.

Note 9. In this paper, unlike Teoh et al. accruals are scaled by the average of total assets.

\section{Copyrights}

Copyright for this article is retained by the author(s), with first publication rights granted to the journal.

This is an open-access article distributed under the terms and conditions of the Creative Commons Attribution license (http://creativecommons.org/licenses/by/3.0/). 